\title{
Application of nanosilver based preparation in ammonia reduction in broiler house
}

\author{
Katarzyna Czyż', Bożena Patkowska-Sokoła', Zbigniew Dobrzański² and Sebastian \\ Opaliński²
}

'Institute of Animal Breeding, ${ }^{2}$ Department of Environment Hygiene and Animal Welfare, Wroclaw University of Environmental and Life Sciences, Wrocław, Poland

\begin{abstract}
The aim of the study was to determine the dose of a nanotechnological-mineral preparation based on nanosilver and vermiculite for an effective ammonia reduction, and the influence of the preparation on physical properties of litter and air. The preparation used was obtained by spreading water nanosilver suspension on vermiculite with an addition of $5 \%$ of humodetrynite. Research animals were broiler chickens divided into three groups. The particular groups were differentiated regarding the prepared application. The measurements of ammonia concentrations were conducted in upper litter layer and about $30 \mathrm{~cm}$ above the litter. Litter temperature, humidity and $\mathrm{pH}$, and air humidity and temperature were monitored. The measurements were conducted at day 5, 10, 15, 20 and 25 of the experiment. Ammonia content above the litter was reduced in group I and II. The highest ammonia concentration was observed in the control group at sampling four while the lowest one was noted in group II at sampling two. In all groups an influence of the preparation on ammonia content above the litter was visible. Decrease in ammonia concentration in experimental groups compared to the control group was more distinct than in the case of ammonia concentration above the litter. Based on the results it is difficult to determine unequivocally an influence of the preparation on litter temperature, $\mathrm{pH}$ and humidity, and also on air temperature and humidity. Taking into account the level of ammonia reduction, the results may be a premise for further studies in the range of nanosilver application for the sanitization of animal buildings.
\end{abstract}

Keywords: nanosilver, vermiculite, ammonia, broiler house

Abbreviations: EBI: European Broiler Index

Archiv Tierzucht 56 (2013) 82, 823-832

Received: 5 November 2012

doi: $10.7482 / 0003-9438-56-082$

Accepted: 16 July 2013

Online: 12 August 2013

Corresponding author:

Katarzyna Czyz; email: katarzyna.czyz@interia.eu

Institute of Animal Breeding, Wroclaw University of Environmental and Life Sciences, Chełmońskiego 38c, 51-630 Wrocław, Poland

() 2013 by the authors; licensee Leibniz Institute for Farm Animal Biology (FBN), Dummerstorf, Germany.

This is an Open Access article distributed under the terms and conditions of the Creative Commons Attribution 3.0 License

(http://creativecommons.org/licenses/by/3.0/). 


\section{Introduction}

Issues connected to the limitation of the emission of harmful substances of agricultural origin, including animal production, into the environment are still one of the most significant problems related to environment protection. Various law regulations, directives or international agreements introduce increasingly growing limitations aimed at the reduction of pollutions coming from animals breeding, what results in the need of new, effective and safe methods for that problem fighting. Moreover, increasing number of complaints from people exposed to emissions of odours from animal production is observed. Odours, including ammonia which is one of the most harmful and concurrently most common odorants, have a significant influence on the life of people inhabiting areas in the vicinity of animal production farms, since these compounds may cause nausea, stress, irritation or allergy (Hayes et al. 2006, Mills 1995, Nimmermark 2004, Schiffman \& Williams 2005, Witkowska et al. 2006). Volatile organic compounds may exhibit toxic activity, stimulate sensory nerves causing neurochemical changes, and also be a reason of sensorial irritations of eyes, throat and nose. Moreover, an unprofitable influence of odours of agricultural origin on human health may be caused by cognitive and emotional factors (Radon et al. 2004).

One of most common sources of odorants' emission into the environment is animal production which, according to the literature data, may be responsible for even $90 \%$ of total ammonia emission (Battye et al. 2003, Gay \& Knowlton 2005, Korczyński et al. 2008, Misselbrook et al. 2000, Reidy et al. 2008, Sotiropoulou et al. 2004). The most visible effects of ammonia emission reduction are observed when adding chemical, mineral or microbiological preparations to the bedding, which neutralize ammonia and other gases release and also exhibit bactericidal and deodorization properties. The activity of preparations used includes ammonia binding in stable chemical connections, influence microflora development or physicochemical bedding properties (bedding drying or $\mathrm{pH}$ lowering), what in a consequence causes limitation of uricolytic transformations and thus a decrease in the ammonia amount (McCrory \& Hobbs 2001, Meisinger \& Jokela 2000). Chemical control of ammonia emission from the bedding seems to be relatively simple, because ammonia easily reacts with other chemical compounds. The advantage of the chemical agent used for this purpose should be the lack of toxic activity, low cost and easy application. To neutralize ammonia activity in inventory buildings the following agents are used: formaldehyde, burnt lime, superphosphate, organic acids (acetic, propionic), different fungicidal preparations. Also, as an alternative for chemical compounds, also natural preparations in a form of zeolites, aluminosilicates, dolomites, some varieties of brown coal, peat preparations, or recently preparations containing saponins, are used more often (Duggan et al. 2001, Gutarowska et al. 2009). There are also some attempts of novel biofilter application in elimination of odours, endotoxins, bacteria and other pollutants from livestock objects (Tymczyna et al. 2004, Chmielowiec-Korzeniowska et al. 2007, Tymczyna et al. 2007)The present ways of optimization of animals maintenance in inventory buildings, e.g. by disinfection practices, bedding or manure additives in a form of mineral, microbiological or chemical preparations, do not solve however the problems, the more that many of them cannot be applied in the presence of animals (Stringfellow et al. 2009). 
There is still a search for universal preparations, limiting microflora development, and thus gases emission, mainly ammonia, from bedding (with animals manure), which would be concurrently safe for the animals and environment. It is also significant, that the substances applied improve fertilizing value of manure, droppings etc. which play more and more significant role in fertilization (especially on organic farms and in gardening), according to sustainable agriculture rule. Probably, such a mean may be nanosilver, which is lately often used in various nanotechnological applications, and is continuously a subject of extensive research (e.g. Pulit et al. 2012).

The aim of the study conducted was an attempt to determine the dose of a nanotechnological-mineral preparation based on nanosilver and vermiculite for an effective ammonia reduction, and the influence of the preparation used on physical properties of litter and air.

\section{Material and methods}

Nanotechnological preparation used in the study was obtained by spreading a water nanosilver suspension (Amepox, Łódź, Poland) on mineral sorbent. Expanded vermiculite of Rominco Poland Company was used as a sorbent, with an addition of $5 \%$ of humodetrynite in order to increase sorptive capacity. Nanosilver suspension of a concentration of $1000 \mathrm{ppm}$ was spread on a sorbent at room temperature in an amount of $100 \mathrm{ml} / 1 \mathrm{~L}$ of sorbent $(\mathrm{v} / \mathrm{v})$. This way the friable preparation of a solid consistence was obtained.

Research animals were broiler chickens of Ross 308 line aged two weeks. Three research groups were formed by randomly assigned 84 broilers ( 28 birds in each group). The chickens were maintained on straw-sawdust litter of 1:1 ratio of particular components, while particular groups were differentiated regarding the application of nanotechnologicalmineral preparation: Control group (C) - without preparation addition; Group I - preparation addition in amount of $15 \mathrm{~L}$ (i.e. $1.5 \mathrm{~L}$ of nanosilver suspension in the volume) under litter surface - once at the beginning of the experiment; Group II - preparation addition in amount of $15 \mathrm{~L}$ mixed with litter, and next added during each straw and sawdust addition, i.e. at day $3,10,17$ and 24 of the experiment.

Straw and sawdust were added at the same days without the preparation also in the control group and group I.

Body weight of broilers was determined at the beginning and at the end of the experiment, and during the whole experimental period feed consumption and number of collapses were noted. Based on the data collected, the basic production parameters; i.e. body weight gain, feed utilization and percentage of collapsed birds; were calculated. Moreover, for the whole rearing period, the European Broiler Index (EBI) was calculated according to the following formula:

$$
E B I=\frac{\text { survival rate }(\%) x \text { body weight }(\mathrm{kg})}{\text { length of rearing period (days) feed utilization for } 1 \mathrm{~kg} \text { of bady weigth }(\mathrm{kg})} \cdot 100
$$

Broilers were fed according to recommendations included in Standards of Poultry Feeding (Smulikowska \& Rutkowski 2005) with complete mixtures of GROWER and next FINISHER type of Provimi Polska Sp. z o.o. company (Provimi, Warszawa, Poland). 
The measurements of ammonia concentrations were conducted in upper layer of litter (samples collection on a depth of about $2-3 \mathrm{~cm}$ ), and also its content about $30 \mathrm{~cm}$ above the litter was determined. The air for analysis was collected using AMZ-1 aspirators (Rotametr, Gliwice, Poland) with the air flow at the level of $60 \mathrm{~L} / \mathrm{h}$. In the case of ammonia emission from upper layer of litter $15 \mathrm{~L}$ of air were collected each time, while when analysing ammonia content above the litter, $30 \mathrm{~L}$ of air for analysis were collected. The content of ammonia collected in each sample was determined in triplicates.

The content of ammonia was determined using colorimetric method according to Polish standard PN-71Z-04041 using SEMCO UV-VIS spectrophotometer (Emco, Łysomice, Poland). Temperature and pH of litter was determined using pHmeter (Dramiński, Olsztyn, Poland), and humidity of litter was determined using moisture meter of the same company. Humidity and temperature of an air were monitored using thermohygrometer of Elementron Company (Elementron, Zabrze, Poland). Measurements of physical features of air and litter were conducted three times, and the results were presented as means from the three measurements. Analyses of ammonia concentration and physical parameters of litter were conducted at day 5, 10, 15, 20 and 25 of the experiment (i.e. sampling 1, 2, 3, 4, 5 and 6). The study was conducted with an agreement of 2 nd Local Ethical Commission for the experiments on animals in Wroclaw (agreement no 115/2007 of 22 October 2007).

The results were subjected to statistical analysis using two-factor analysis of variance with an application of Statistica 8.0 software (StatSoft, Inc. Tulsa, OK, USA). Mean values and standard deviations were calculated. Significance of differences between the groups was determined using Duncan's test with significance level of $P<0.05$ and $P<0.01$.

\section{Results}

The indices concerning reared broiler chickens, i.e. initial and final body weight, mortality rate, mean feed consumption and EBI were presented in Table 1.

Table 1

Indices of broiler chickens rearing (mean values)

\begin{tabular}{lccc}
\hline Index & C & Group & \\
& 84 & $\mathrm{I}$ & II \\
\hline Initial number of chickens & 80 & 84 & 84 \\
Final number of chickens & 4.8 & 81 & 80 \\
Mortality rate, $\%$ & 400.0 & 3.6 & 4.8 \\
Initial body weight, g & 1730.0 & 1830.0 & 420.0 \\
Final body weight, g & 1330.0 & 1431.0 & 1842.0 \\
Body weight gain, g & 119 & 121 & 1422.0 \\
Feed consumption, g/head/day & 2.15 & 2.03 & 120 \\
Feed consumption, kg/kg of body weight gain & 319.2 & 362.1 & 2.02 \\
European Broiler Index, pts & & & 361.7 \\
\hline
\end{tabular}

The initial body weight was slightly higher in chickens from group II compared to other groups. Body weight gain during the whole experimental period was the highest in group $\mathrm{I}$, and the lowest in the control group. Mortality rate in turn was on the same level, i.e. $4.8 \%$ in the control group and group II, while the lowest was found on a level of $3.6 \%$ in group I. 
Mean feed consumption was similar in all the groups and was 119, 121 and $120 \mathrm{~g} / \mathrm{head} /$ gay, respectively. EBI index in the control group was 319.2, while in groups I and II it was 362.1 and 361.7, respectively. The tendency for better feed utilization by chickens from experimental groups was observed, what was reflected in higher EBI index in these groups.

The values concerning ammonia emission above the litter and concentration of that gas in upper layer of litter for the control group and for experimental ones, where nanotechnologicalmineral preparation was added, were presented in Table 2.

Table 2

Ammonia concentration above the litter and in upper layer of litter (mean \pm SD)

\begin{tabular}{cccc}
\hline Sampling & Control group (C) & Group I & Group II \\
\hline Ammonia concentration above litter, ppm & & \\
1 & $20.84^{\mathrm{a}} \pm 2.09$ & $18.72 \pm 1.84$ & $16.03^{\mathrm{b}} \pm 1.58$ \\
2 & $23.16^{\mathrm{A}, \mathrm{a}} \pm 2.85$ & $20.12^{\mathrm{a}} \pm 1.67$ & $15.47^{\mathrm{B}, \mathrm{b}} \pm 2.07$ \\
3 & $24.93^{\mathrm{a}} \pm 3.01$ & $21.54 \pm 1.28$ & $19.39^{\mathrm{b}} \pm 1.50$ \\
4 & $27.26^{\mathrm{a}} \pm 2.05$ & $24.38 \pm 2.21$ & $21.72^{\mathrm{b}} \pm 2.02$ \\
5 & $26.51^{\mathrm{A}, \mathrm{a}} \pm 2.44$ & $23.87^{\mathrm{A}} \pm 3.35$ & $17.77^{\mathrm{B}, \mathrm{b}} \pm 1.75$ \\
6 & $25.88^{\mathrm{A}, \mathrm{a}} \pm 2.40$ & $22.35^{\mathrm{a}} \pm 1.71$ & $16.23^{\mathrm{B}, \mathrm{b}} \pm 1.96$ \\
Ammonia concentration in upper layer of litter, ppm & & \\
1 & $35.35^{\mathrm{A}, \mathrm{a}} \pm 4.21$ & $23.77^{\mathrm{B}, \mathrm{b}} \pm 2.68$ & $22.18^{\mathrm{B}, \mathrm{b}} \pm 1.82$ \\
2 & $36.90^{\mathrm{A}, \mathrm{a}} \pm 3.33$ & $21.17^{\mathrm{B}, \mathrm{b}} \pm 2.11$ & $18.87^{\mathrm{B}, \mathrm{b}} \pm 1.81$ \\
3 & $38.68^{\mathrm{A}, \mathrm{a}} \pm 2.75$ & $26.94^{\mathrm{B}, \mathrm{b}} \pm 3.02$ & $22.62^{\mathrm{B}, \mathrm{b}} \pm 2.50$ \\
4 & $36.84^{\mathrm{A}, \mathrm{a}} \pm 2.97$ & $21.13^{\mathrm{B}, \mathrm{b}} \pm 2.72$ & $18.23^{\mathrm{B}, \mathrm{b}} \pm 1.89$ \\
5 & $31.66^{\mathrm{A}, \mathrm{a}} \pm 3.18$ & $18.92^{\mathrm{B}, \mathrm{b}} \pm 1.91$ & $17.46^{\mathrm{B}, \mathrm{b}} \pm 2.31$ \\
6 & $29.17^{\mathrm{A}, \mathrm{a}} \pm 2.68$ & $16.71^{\mathrm{B}, \mathrm{b}} \pm 2.02$ & $14.18^{\mathrm{B}, \mathrm{b}} \pm 2.22$ \\
\hline
\end{tabular}

A,BValues in rows marked with different letters differ at $P<0.01$. a,bValues in rows marked with different letters differ at $P<0.05$.

Ammonia content above the litter was reduced in group I and II compared to the control group. The highest ammonia concentration was observed in the control group at sampling four (27.26 ppm), while the lowest one was noted in group II at sampling two (15.47 ppm). It was observed that in group II, i.e. the group where the preparation was mixed with litter and introduced with each litter addition, the reduction of ammonia concentration above the litter was higher compared to group I where the preparation was applied only once under the litter at the beginning of the experiment. In both groups reduction of ammonia concentration influenced by an addition of nanotechnological-mineral preparation to the litter was noted in comparison to the control group. In all the groups, including the control one, an influence of litter addition on ammonia content above the litter was visible. It was the most distinct in all the groups after 3rd litter adding, when decrease in ammonia concentration with respect to previous sampling was $0.75,0.51$ and as much as $3.95 \mathrm{ppm}$ in the control group, group I and II, respectively.

The concentration of ammonia in the upper litter layer also decreased in the groups where an addition of preparation with nanosilver was applied to the litter. That concentration was in the range from $14.18 \mathrm{ppm}$ (group II, sampling six) to $38.68 \mathrm{ppm}$ (control group, sampling three). Decrease in ammonia concentration in experimental groups (I and II) compared to the control group was more distinct than in the case of ammonia concentration above the litter. 
Also in that case an influence of litter adding on ammonia emission was noted, also in the control group where nanotechnological-mineral preparation was not used. That influence was the most distinct after 2 nd litter adding, and decreasing tendency was maintained at the end of the experimental period.

Physical parameters of the litter, i.e. its temperature, humidity and $\mathrm{pH}$, are presented in Table 3.

Table 3

Physical parameters of litter (mean \pm SD)

\begin{tabular}{lrrr}
\hline Sampling & Control group (C) & Group I & Group II \\
\hline Temperature, ${ }^{\circ} \mathrm{C}$ & & & \\
1 & $26.3 \pm 0.9$ & $25.1 \pm 1.2$ & $28.5 \pm 0.8$ \\
2 & $29.8 \pm 1.3$ & $28.5 \pm 1.1$ & $33.1 \pm 1.5$ \\
3 & $29.3 \pm 1.1$ & $26.3 \pm 0.9$ & $29.2 \pm 1.2$ \\
4 & $28.1 \pm 0.7$ & $27.2 \pm 0.8$ & $30.3 \pm 1.1$ \\
5 & $32.7 \pm 1.4$ & $29.4 \pm 1.2$ & $32.8 \pm 1.5$ \\
6 & $35.3 \pm 1.1$ & $34.2 \pm 0.9$ & $33.9 \pm 1.3$ \\
Humidity, \% & & & \\
1 & $40.2 \pm 3.6$ & $37.9 \pm 1.9$ & $31.5 \pm 5.0$ \\
2 & $54.1 \pm 4.9$ & $42.1 \pm 4.6$ & $46.3 \pm 3.9$ \\
3 & $60.8 \mathrm{a} \pm 3.2$ & $48.7 \mathrm{a} \pm 6.2$ & $38.7 \mathrm{~b} \pm 2.5$ \\
4 & $56.1 \pm 1.7$ & $52.6 \pm 5.8$ & $56.1 \pm 4.9$ \\
5 & $58.5 \pm 5.1$ & $62.1 \pm 3.8$ & $66.3 \pm 5.3$ \\
6 & $68.2 \pm 4.3$ & $56.2 \pm 4.2$ & $52.8 \pm 3.1$ \\
$\mathrm{pH}$ & & & $7.16 \pm 0.51$ \\
1 & $7.60 \pm 0.38$ & $7.44 \pm 0.41$ & $5.98 \mathrm{~b} \pm 0.38$ \\
2 & $7.30 \mathrm{a} \pm 0.53$ & $6.08 \mathrm{~b} \pm 0.52$ & $5.59 \mathrm{~b} \pm 0.31$ \\
3 & $6.75 \mathrm{a} \pm 0.29$ & $6.21 \pm 0.39$ & $6.27 \pm 0.29$ \\
4 & $6.55 \pm 0.61$ & $5.64 \pm 0.42$ & $5.56 \pm 0.42$ \\
5 & $5.91 \pm 0.35$ & $5.74 \pm 0.31$ & $7.16 \pm 0.51$ \\
6 & $7.60 \pm 0.38$ & $7.44 \pm 0.40$ & \\
\hline
\end{tabular}

${ }^{a, b}$ Values in rows marked with different letters differ at $P<0.05$.

Litter temperature observed during the experiment was on a level from $25.1^{\circ} \mathrm{C}$ (group I, sampling one) to $33.3^{\circ} \mathrm{C}$ (group C, sampling six). Based on the results obtained it is difficult to determine unequivocally an influence of nanotechnological-mineral preparation applied on litter temperature. Humidity of litter in turn was on a level from 31 (group II, sampling one) to $38 \%$ (group C, sampling six). Similarly like in the case of the temperature, the relationship between preparation used and litter humidity is not clear. Also $\mathrm{pH}$ values which were within the range from 5.56 (group II, sampling five) to 7.60 (groups C, samplings one and six) do not demonstrate a clear relationship between preparation addition and the litter.

Table 4 presents physical parameters of air, i.e. temperature and humidity determined with each sampling during the whole experimental period.

Air temperature in experimental boxes observed during the experiment was on a level from $19.7^{\circ} \mathrm{C}$ (group I, sampling 4) to $28.3^{\circ} \mathrm{C}$ (group II, sampling six), while humidity of air ranged from 60.3 (group C, sampling three) to $71.0 \%$ (group I, sampling two). Like in the case of physical parameters of litter, the clear relationship between air temperature and humidity and nanotechnological-mineral preparation addition to the litter is difficult to determine. 
Table 4

Physical parameters of air (mean \pm SD)

\begin{tabular}{lccc}
\hline Sampling & Control group $(\mathrm{C})$ & Group I & Group II \\
\hline Temperature, ${ }^{\circ} \mathrm{C}$ & & & \\
1 & $25.8 \pm 1.2$ & $26.0 \pm 1.2$ & $26.5 \pm 0.9$ \\
2 & $26.1 \pm 0.9$ & $24.6 \pm 0.7$ & $26.6 \pm 1.1$ \\
3 & $25.5 \pm 1.1$ & $23.7 \pm 1.1$ & $25.8 \pm 0.7$ \\
4 & $21.4 \pm 0.7$ & $19.7 \pm 0.7$ & $23.3 \pm 1.0$ \\
5 & $26.3 \pm 1.3$ & $24.5 \pm 1.3$ & $27.9 \pm 0.9$ \\
6 & $27.5 \pm 0.8$ & $26.8 \pm 1.2$ & $28.3 \pm 1.2$ \\
Humidity, \% & & & \\
1 & $67.2 \pm 5.8$ & $62.8 \pm 4.9$ & $63.2 \pm 7.1$ \\
2 & $67.7 \pm 4.6$ & $71.0 \pm 6.3$ & $60.4 \pm 5.9$ \\
3 & $60.3 \pm 3.9$ & $63.5 \pm 3.9$ & $61.4 \pm 5.8$ \\
4 & $70.1 \pm 6.2$ & $70.4 \pm 4.7$ & $61.2 \pm 3.9$ \\
5 & $61.7 \pm 5.3$ & $63.6 \pm 5.3$ & $65.7 \pm 4.5$ \\
6 & $64.3 \pm 4.2$ & $65.1 \pm 3.5$ & \\
\hline
\end{tabular}

All physical parameters, both of litter and air, were undoubtedly affected by atmospheric conditions observed during the experimental period, i.e. temperature and humidity outside the experimental boxes. Also the animals and procedures connected to their feeding, watering, or litter adding, as well as room's ventilation would have influenced these results.

\section{Discussion}

No distinct influence of preparation based on vermiculite and water nanosilver suspension on presented rearing results was observed. It probably results from the fact that birds productivity is influenced by a range of factors, and a too small number of observations does not allow to draw conclusions in that range.

There are numerous papers in the literature available concerning the problem of ammonia emission and physical parameters of litter and air in livestock buildings. High differentiations of conditions, assumptions and results in other authors' studies show however, that a direct confrontation of the results obtained in the present study with results obtained by other authors is not easy and an unequivocal issue.

Nicholson et al. (2004) conducted the study concerning ammonia emission from litter in broiler house depending on kind and amount of litter, and also kind of drinkers and litter humidity. They observed that ammonia losses in the winter period were higher in the case of straw litter compared to sawdust one. It was probably caused by e.g. higher mass of sawdust litter compared with straw litter. In the summer period in turn, ammonia losses were almost two fold higher compared to the winter period, irrespectively in litter kind, what was caused, among others, by higher ventilation rate. No differences in ammonia emission were observed depending on litter amount, both in winter and summer. Similar results were obtained by Elwinger \& Svensson (1996), who analysed the relationship of ammonia emission between kind and amount of litter in broiler house and also kind or drinker used (bell and nipple). No significant differences caused by kind or amount of litter were observed in this study. 
It was observed in numerous studies that kind of drinker influences significantly litter humidity and thus ammonia emission (Tucker \& Walker 1992). In the study by Nicholson et al. (2004) ammonia emission was higher in the case of more humid litter compared with litter of lower humidity. It was connected to the kind of drinker used (bell and nipple). Similar results were obtained by Elwinger \& Svensson (1996).

Vučemilo et al. (2007) analysed an influence of broilers' age on degree of air contamination in the broiler house. Ammonia emission noted by these authors depended on the birds' age. The lowest value was noted at 1st week, what was connected to the fact that broilers were placed on a fresh litter (straw-sawdust), while the highest values were observed at 3rd and 5th week, what was connected to the birds' age and also to air humidity. Hayes et al. (2006) conducted a study concerning ammonia emission in intense breeding poultry farms in Ireland. In the case of broilers, ammonia concentration depended on the season of the year. Seedorf \& Hartung (1999) conducted a study on ammonia concentration in animal buildings. In the case of broilers, the mean ammonia concentration was the highest among all the species analysed. Also an influence of temperature and humidity on ammonia production and release in poultry was observed. Liu et al. (2007) in turn, performed controlled laboratory tests aimed to determine an influence of litter humidity in broilers on ammonia emission. They observed a distinct relationship between these parameters. Herbut et al. (2010) undertook an attempt to determine odours emission, including ammonia, from poultry production. The authors observed considerable differentiation in gas emission in broiler production, depending on used system of birds' maintenance. Lower ammonia emission was noted in case of cage maintenance system compared to shallow litter. The values of temperature and relative humidity inside the buildings were also dependent on maintenance system.

Tasistro et al. (2006) analysed the influence of an additive aimed to terminate nitrification process on the reduction of ammonia emission from broiler litter. They used an addition of clay soil to the litter and obtained ammonia emission reduction of about $3 \%$ at the beginning of the experiment and about $21 \%$ after 48 hours. Atapattu et al. (2008) examined ammonia emission from three various kinds of broiler litters. They used tea wastes, sawdust and rice peeling wastes as litter. Ammonia emission was on the lowest level in case of tea wastes, while the highest one was noted for sawdust. The value of $\mathrm{pH}$ was not differentiated depending on litter kind, while humidity level was slightly differentiated. A study conducted by Witkowska et al. (2006) revealed that ammonia level was two-fold reduced using commercial disinfectant compared to the control, untreated group. In turn, an application of open biofilter in the laying house resulted in stabilization of moisture, reaction, temperature in air, and also reduced ammonia content on a level from 36 to $89 \%$ (Tymczyna et al. 2004).

In the view of literature data, the results obtained in the present study may be considered as satisfactory. Taking into account the amount of ammonia emission reduction, these results may be a premise for further studies in the range of nanosilver application in the sanitization of animal buildings.

\section{Acknowledgements}

The study was conducted within the research project No N N205 018634 financed by Polish Ministry of Science and Higher Education. 


\section{References}

Atapattu NSBM, Senaratna D, Belpagodagamage UD (2008) Comparison of Ammonia Emission Rates from Three Types of Broiler Litters. Poult Sci 87, 2436-2440

Battye W, Aneja VP, Roelle PA (2003) Evaluation and improvement of ammonia emissions inventories. Atmos Environ 37, 3873-3883

Chmielowiec-Korzeniowska A, Tymczyna L, Skórska C, Sitkowska J, Cholewa G, Dutkiewicz J (2007) Efficacy of novel biofilter in hatchery sanitation: I. Removal of airborne bacteria, dust and endotoxin. Ann Agric Environ Med 14, 141-150

Duggan J, Bates MP, Phillips CA (2001) The efficacy of subsurface flow reed bed treatment in the removal of Campylobacter spp., faecal coliforms and Escherichia coli from poultry litter. Int J Environ Health Res 11, $168-180$

Elwinger K, Svensson L (1996) Effect of Dietary Protein Content, Litter and Drinker Type on Ammonia Emission from Broiler Houses. J Agric Eng Res 64, 197-208

Gay SW, Knowlton KF (2005) Ammonia Emissions and Animal Agriculture. Virginia Cooperative Extension, Publication 442-110

Gutarowska B, Borowski S, Durka K, Korczyński M, Kołacz R (2009) Selection of microorganisms able for odor compounds removing from poultry droppings. Przemysł Chem 88, 440-445 [in Polish]

Hayes ET, Curran TP, Dodd VA (2006) Odour and ammonia emissions from intensive poultry units in Ireland. Biores Technol 97, 933-939

Herbut E, Walczak J, Krawczyk W, Szewczyk A, Pająk T (2010) Odour emissions from poultry production. In: Pollution and Organic Aspects of Animal Production, Wyd. IZ PIB, Kraków, Poland, 58-70

Korczyński M, Opaliński S, Gbiorczyk W, Dobrzański Z, Kołacz R (2008) Application of bentonite and vermiculite to limit the emission of ammonia from cattle manure. Chemistry for Agriculture 9, 543-548

Liu Z, Wang L, Beasley D, Oviedo E (2007) Effect of moisture content on ammonia emissions from broiler litter: A laboratory study. J Atmos Chem 58, 41-53

McCrory DF, Hobbs PJ (2001) Additives to Reduce Ammonia and Odor Emissions from Livestock Wastes. J Environ Qual 30, 345-355

Meisinger JJ, Jokela WE (2000) Ammonia Volatilization from Dairy and Poultry Manure. NRAES-130, Ithaca, NY, USA (https://dairyn.cornell.edu/pages/20cropsoil/documents/MeisingerandJokela-NRAES130-2000.pdf)

Mills B (1995) Review of methods of odour control. Filtration and Separation 147-152

Misselbrook TH, Van Der Weerden TJ, Pain BF, Jarvis SC, Chambers BJ, Smith KA, Phillips VR, Demers TGM (2000) Ammonia emission factors for UK agriculture. Atmos Environ 34, 871-880

Nicholson FA, Chambers BJ, Walker AW (2004) Ammonia Emissions from Broiler Litter and Laying Hen Manure Management Systems. Biosyst Eng 89, 175-185

Nimmermark S (2004) Odour influence on well-being and health with specific focus on animal production emissions. Ann Agric Environ Med 11, 163-173

Pulit J, Banach M, Tymczyna L, Chmielowiec-Korzeniowska A (2012) State of research and trends in the preparation of nanostructured silver. Przemysł Chem 91 (5), 929-936 [in Polish]

Radon K, Peters A, Praml G, Ehrenstein V, Schulze A, Hehl O, Nowak D (2004) Livestock odours and quality of life of neighbouring residents. Ann Agric Environ Med 11, 59-62

Reidy B, Rhim B, Menzi H (2008) A new Swiss inventory of ammonia emissions from agriculture based on a survey on farm an manure management and farm-specific model calculations. Atmos Environ 42, 32663276

Schiffman SS, Williams CM (2005) Science of Odor as a Potential Health Issue. J Environ Qual 34, 129-138

Seedorf J, Hartung J (1999) Survey of ammonia concentrations in livestock buildings. J Agric Sci 133, 433-437

Smulikowska S, Rutkowski A (2005) [Standards of poultry feeding. Mutritional recommendations and nutritional value of fodders]. Instytut Fizjologii i Żywienia Zwierząt PAN, 1- 135 [in Polish] 
Sotiropoulou REP, Tagaris E, Pilinis C (2004) An estimation of the spatial distribution of agricultural ammonia emissions in the Greater Athens Area. Sci Total Environ 318, 159-169

Stringfellow K, Anderson P, Caldwell D, Lee J, Byrd J, McReynolds J, Carey J, Nisbet D, Farnell M (2009) Evaluation of disinfectants commonly used by the commercial poultry industry under simulated field conditions. Poult Sci 88, 1151-1155

Tasistro AS, Cabrera ML, Kissel DE, Ritz CW (2007) Study on the reduction of NH3 volatilization from broiler litter through the promotion of nitrification. J Environ Sci Health A Tox Hazard 42, 549-556

Tucker SA, Walker AW (1992) Hock burn in broilers. In: Garnsworthy PC, Haresign W, Cole DJA (eds.) Recent Advances in Animal Nutrition. Butterworth-Heinemann Ltd., Oxford, UK 33-49

Tymczyna L, Chmielowiec-Korzeniowska A, Saba L (2004) Biological Treatment of Laying House Air with Open Biofilter Use. Polish J Environ Stud 13, 425-428

Tymczyna L, Chmielowiec-Korzeniowska A, Drabik A, Skórska C, Sitkowska J, Cholewa G, Dutkiewicz J (2007) Efficacy of a novel biofilter in hatchery sanitation: II. Removal of odorogenous pollutants. Ann Agric Environ Med 14, 151-157

Witkowska D, Sowińska J, Iwańczuk-Czernik K, Mituniewicz T, Wójcik A, Szarek J (2006) The effect of a disinfectant on the ammonia concentration on the surface of litter, air and the pathomorphological picture of kidneys and livers in broiler chickens. Arch Tierz 49, Special Issue, 249-256

Vučemilo M, Matković K, Vinković B, Jakšić S, Granić K, Mas N (2007) The effect of animal age on air pollutant concentration in a broiler house. Czech J Anim Sci 52, 170-174 